\title{
Energy Fluxes and Evapotranspiration in a Rubber Agroecosystem of the Southern Thailand
}

\author{
Watcharee RUAIRUEN ${ }^{1, *}$, Gilberto J. FOCHESATTO ${ }^{2}$, \\ Poonpipope KASEMSAP ${ }^{3,4}$ and Chompunut CHAYAWAT ${ }^{4}$
}

${ }^{I}$ Environmental Science and Technology Program, Faculty of Science and Technology, Suratthani Rajabhat University, Surat Thani 84100, Thailand

${ }^{2}$ Department of Atmospheric Sciences, Geophysical Institute and College of Natural Science and Mathematics, University of Alaska Fairbanks, Fairbanks, Alaska 99775, USA

${ }^{3}$ Department of Horticulture, Faculty of Agriculture, Kasetsart University, Bangkok 10900, Thailand

${ }^{4}$ DORAS Centre, Kasetsart University, Bangkok 10900, Thailand

("Corresponding author's e-mail: watcharee.rua@sru.ac.th, ruairuen@gmail.com)

Received: 10 March 2019, Revised: 2 March 2020, Accepted: 11 April 2020

\begin{abstract}
Evapotranspiration (ET) plays an important role in land surface atmosphere interaction which significantly drives hydrological cycle, vegetation functioning resulting to agricultural production. In this study, observations of energy fluxes, energy partitioning, and evapotranspiration (ET) were conducted on a monoclonal stand of rubber trees (Hevea brasiliensis) plot (clone RRIM 600) in 2017. The forestry population was 17 years old and had been tapped continuously over 10 years for latex harvesting at the Rubber Estate Organization station in Na Bon district, Nakhon Si Thammarat province in Thailand. The ET rate and associated energy fluxes were determined by means of eddy covariance (EC) method and complemented by micrometeorological measurements at $25 \mathrm{~m}$ tall tower. Tree stands were spaced on plots of $3.0 \times 7.0 \mathrm{~m}^{2}$ with mean canopy height of $22 \mathrm{~m}$. Data were collected during January 1 to September 27,2017 . Results found that the energy balance closure of the rubber agroecosystem was approximately $78 \%$. Overall, the latent heat (LE) flux was the main term of energy exchange $(58-60 \%)$ due to its dominance across the growing season. The ratios of the latent heat (LE) and sensible heat (H) to net radiation were 0.58 and 0.24 throughout the period of study, respectively. Moreover, the daily mean of evapotranspiration (ET) was $7.16 \mathrm{~mm} \cdot \mathrm{d}^{-1}$ over the whole period of this study. However, a slightly higher rate of daily mean ET $\left(7.35 \mathrm{~mm} \cdot \mathrm{d}^{-1}\right)$ was indicated during the foliage period than during the leaf senescence period due to sufficient soil moisture associated with high rate of seasonal precipitation. It is concluded, that ET is an extremely sensitive variable to understand in energy flow in this ecosystems as well as a precursor for presetting condition for droughts prognosis (forecast) in a rubber ecosystem.
\end{abstract}

Keywords: Evapotranspiration, Energy fluxes, Rubber agroecosystem, Eddy covariance, Southern Thailand

\section{Introduction}

Thailand is the world's largest producer and exporter of natural rubber, accounting for about onethird of world's supply [1]. The major producing regions are in Southern Thailand where climatic conditions and land use are favorable habitat for rubber forests, particularly in Nakhon Si Thammarat province (latitudes $8-9^{\circ} \mathrm{N}$ ). In fact, this region has forestry production based on mono-cultivars that covers more than 267,795 ha with a production of approximately 442,790 tons according to the Office of Agricultural Economics [2]. This significant expansion of forest production across non-traditional regions especially in mountainous mainland has converted primary and secondary original forests into rubber 
http://wjst.wu.ac.th

plantations. As a result, a large region of potential changes in ecological and environmental regimes have been initiated by decreasing biodiversity, altering hydrological regimes, reducing total carbon biomass, and accelerating surface erosion and water runoff [3-5] and carbon storage [6,7]. A larger area of rubber forest is also creating a microclimate with large water availability for evapotranspiration (ET), which in turn increases the atmospheric specific humidity near the surface having a far more reaching influence on the weather and climate at regional scales. Nevertheless, the observational datasets for energy flux partitioning and evapotranspiration of rubber forests are not yet long enough to establish a clear trend with high confidence on the regional scale influences in weather and climate. The objectives of this research are as follows: To study the characteristics of turbulent fluxes and energy exchanges in different periods of a rubber forest in the Southern Region of Thailand and to determine the contribution of ET and sensible $(H)$ heat fluxes to the available energy of the rubber forest in 2017.
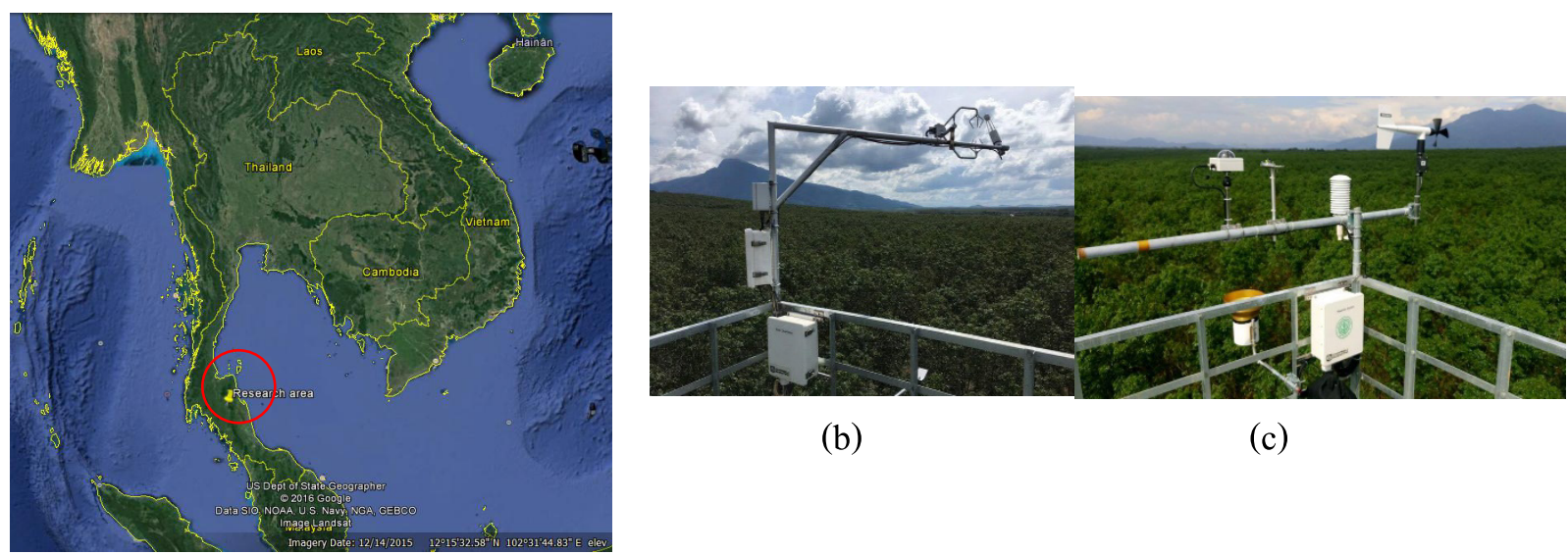

(b)

(c)

(a)

Figure 1 Location and photograph of observation site. Panel on the left illustrate Google map area from Thailand and the region for the field experiment (a). Central and right panel are instrumentation and Rubber forest canopy site. Central panel (b) depicts the eddy-covariance system at $25 \mathrm{~m}$ and panel on the right (c) is the meteorological and radiation instrumentation. The instruments are installed in a scaffolding tower for easy access and control.

\section{Materials and methods}

Field experiments were carried out in a micrometeorological site as part of the Rubber State Organization ( $8^{\circ} 19^{\prime} 9^{\prime \prime} \mathrm{N}, 99^{\circ} 35^{\prime} 12^{\prime \prime} \mathrm{E}, 50 \mathrm{~m}$ elevation), Nakhon Si Thammarat province in the Southern region of Thailand (Figure 1). The observations were conducted on a monoclonal stand of rubber trees (Hevea brasiliensis) plot (clone RRIM 600). The forestry population is 17 years old. Furthermore, the land was relatively regular and had been tapped for over 10 years for latex harvesting. The forest has an average tree diameter of about $20.5 \mathrm{~cm}$ at $1.7 \mathrm{~m}$ height above the ground with the mean

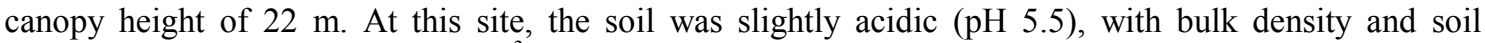
organic carbon contents of $1.0 \mathrm{~g} \mathrm{~cm}^{-3}$ and $2.9 \%$, respectively. The texture of the surface layer $(0-30 \mathrm{~cm})$ of the soil samples was silt loam. Fluxes of energy and water between the rubber tree plantation and the atmosphere were measured from January 1 (day of year; DOY 1) to September 27 (DOY 270), 2017, using the eddy covariance (EC) method. The instruments, which were used to measure the high resolution, high frequency 3-dimensional wind speed components and air temperature, included a 3dimensional sonic anemometer (CSAT3, Campbell Scientific, Inc., Logan, UT, USA). A collocated IRGA 7500 Licor sensor was used to measure water vapor at $10 \mathrm{~Hz}$. Solar radiation was measured at 25 
$\mathrm{m}$ above the ground by Pyranometer (LI-200SA, LI-COR, Inc., Lincoln, NE, USA). In addition, air temperature, air pressure, and relative humidity were also measured at the same height. As part of the energy budget, net radiation $(R n)$ was estimated based on direct solar radiation measurement. All these meteorological data and turbulence fluxes were recorded by a CR1000 (Campbell Scientific, Logan, UT, USA) at a $10 \mathrm{~Hz}$ sampling frequency. Likewise, $30 \mathrm{~min}$ block average fluxes were also determined. Soil heat flux $(G)$ was estimated based on soil thermistors at 2, 4, 6, 16, and $32 \mathrm{~cm}$ depths below surface.

\section{Data processing}

For the retrieval of sensible $(H)$ and latent heat $(L E)$, we used the LoggerNet (Campbell Scientific, Inc., Logan, UT, USA) software in order to transform $10 \mathrm{~Hz}$ raw data into $30 \mathrm{~min}$ binaries. Afterwards, the half-hour $H$ and $L E$ fluxes were calculated by EddyPro version 5.5.1 software following the standard quality control procedures including despiking [8], 2D coordinate rotation, and time lag removal, frequency response correction using model spectra and transfer functions [9], and air density correction [10]. Methodology and signal processing software setup followed similar processing as developed for complex heterogeneous forest [11,12]. The study was divided in 2 sequences: (a) the leaf senescence period including coloration and defoliation stages (January 1, 2017 - February 27, 2017; DOY 30 - 58) and (b) leaf expansion and foliage (March 31, 2017 - September 27, 2017; DOY 90 - 270). In the south of Thailand, usually leaf senescence starts at the end of December, while massive leaf shedding occurs between the end of January and the beginning of February. Therefore, weekly observation of leaves coloring at 5 sub-observation sites began from the $2^{\text {nd }}$ week of December in 2016. Leaf senescence and defoliation period was defined when leaf coloring appeared more than $50 \%$ over all sub-observation sites. On the other hand, leaf expansion and foliage period were also monitored at the same sites by using densitometer for taking measurement of canopy cover. The leaf expansion and foliage stages were determined when more than $40 \%$ of the canopy cover was reached.

\section{Results and discussion}

\section{Meteorological conditions}

The minimum and maximum air temperature $(\mathrm{Ta})$ at $25 \mathrm{~m}$ above the ground were $23.31{ }^{\circ} \mathrm{C}$ (DOY 95; April $5^{\text {th }}$ ) and $28.76^{\circ} \mathrm{C}$ (DOY 160; June $9^{\text {th }}$ ), respectively (Figure 2a). Mean Ta for the whole period of this study was $26.50{ }^{\circ} \mathrm{C}$ with an average approximately of $27^{\circ} \mathrm{C}$ during the leaf senescence and foliage periods (Table 1). The seasonal variation of soil temperature (Ts) at 2, and $6 \mathrm{~cm}$ depths was similar to that of $\mathrm{Ta}$. The minimum and maximum daily soil temperature at $6 \mathrm{~cm}$ were 24.23 and $28.33{ }^{\circ} \mathrm{C}$, respectively with an average of $26.38{ }^{\circ} \mathrm{C}$ (Figure 2b). The total accumulated precipitation during the period of study was $5,296.10 \mathrm{~mm}$, and most of the precipitation was concentrated in January $(1,611 \mathrm{~mm})$ during the early period of leaf senescence of rubber tree. 
(a)

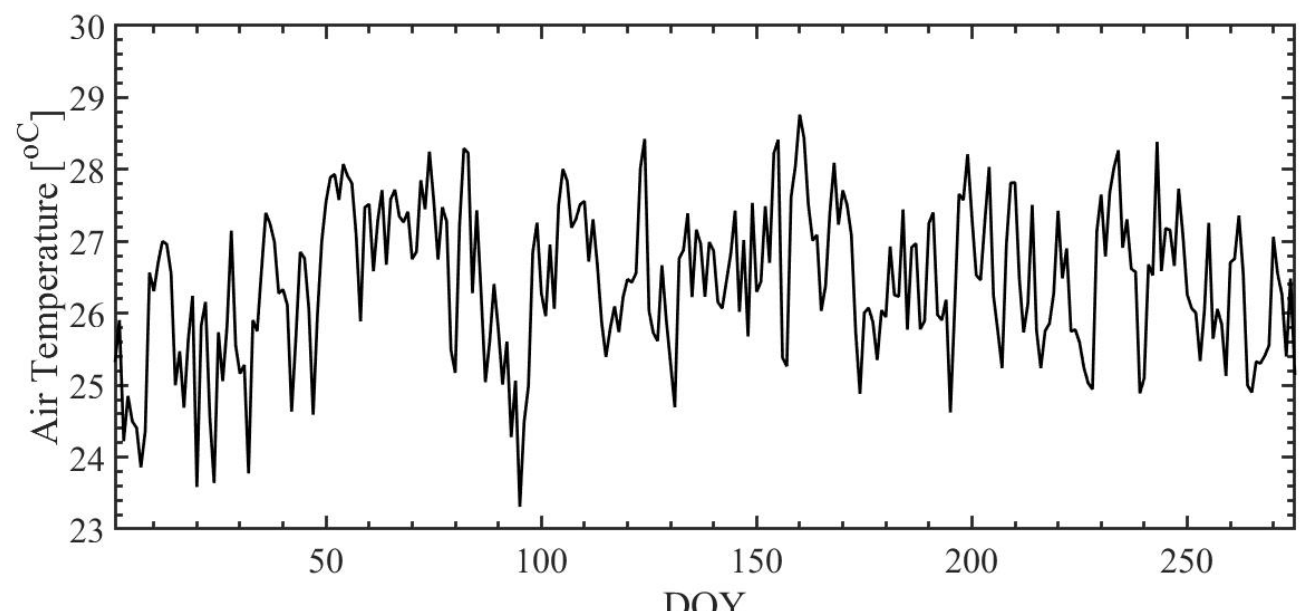

(b)

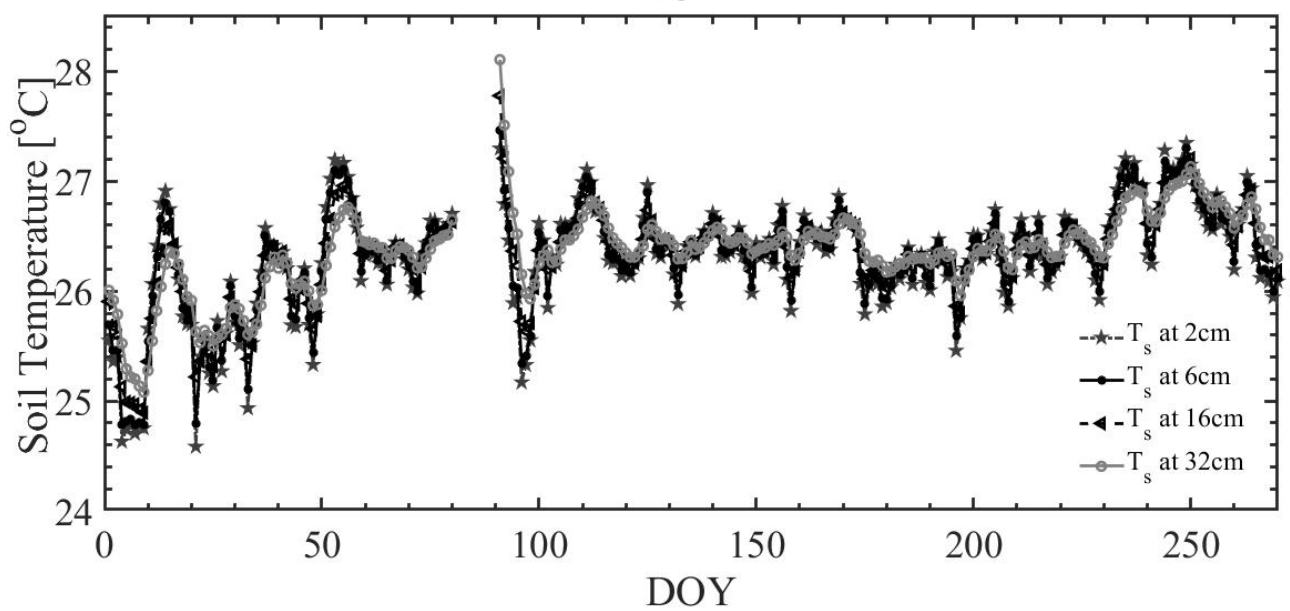

(c)

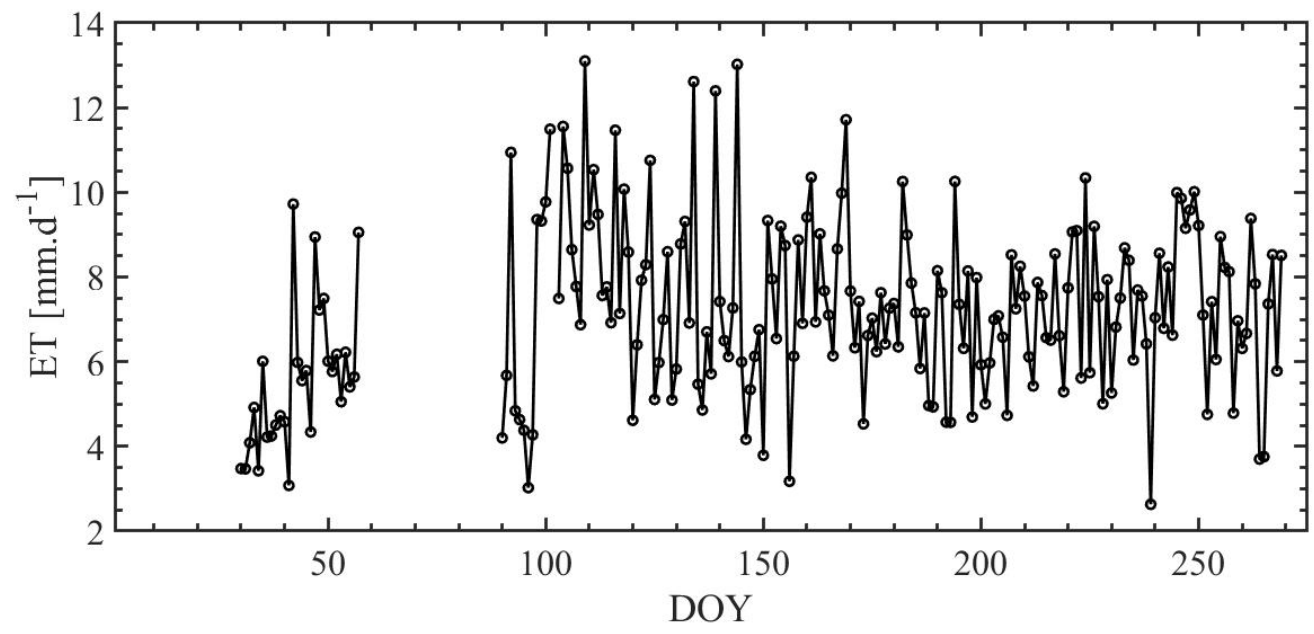

Figure 2 (a) Daily average air temperature (Ta), (b) daily average soil temperature (Ts) and (c) daily accumulated evapotranspiration (ET) ) during January 1 (DOY 1) - September 27 (DOY 270), 2017. 


\section{Diurnal Patterns in Energy Balance Components}

Because of the distinct differences found in the energy partitioning pattern and plant phenology, we divided the study period into 2 sequences: (a) the leaf senescence period including coloration and defoliation stages (DOY 30 - 58); (b) leaf expansion and foliage (DOY 90 - 270). A total of 1,344, 8,640 and 12,912 half-hourly periods were used in the leaf senescence, leaf expansion and foliage, and whole period (DOY 1 - 270), respectively. The values of energy balance components and environmental variables were distinct for the different periods (Table 1).

Table 1 Daily Cumulative Sums of the energy balance components and major biometeorological factors.

\begin{tabular}{lccc}
\hline & $\begin{array}{c}\text { (a) } \\
\text { leaf senescence and } \\
\text { defoliation stage } \\
\text { (DOY 30 - 58) } \\
(\mathbf{n = 1 , 3 4 4 )}\end{array}$ & $\begin{array}{c}\text { (b) } \\
\text { leaf expansion and } \\
\text { foliage stage } \\
(\mathbf{D O Y} \mathbf{9 0}-\mathbf{2 7 0}) \\
(\mathbf{n = 8 , 6 4 0 )}\end{array}$ & $\begin{array}{c}\text { Whole period } \\
\text { (DOY 1 - 270) } \\
(\mathbf{n}=\mathbf{1 2}, \mathbf{9 1 2})\end{array}$ \\
\hline$T a\left({ }^{\circ} \mathrm{C}\right)$ & 27.11 & 26.89 & 26.50 \\
$T \mathrm{~s}\left({ }^{\circ} \mathrm{C}\right)$ & 20.03 & 26.30 & 26.32 \\
$\mathrm{RH}(\%)$ & 71.20 & 87.80 & 71.00 \\
Precipitation $(\mathrm{mm})$ & 70.35 & $3,348.41$ & $3,418.76$ \\
$(\mathrm{sum})$ & & & \\
$R n\left(\mathrm{~W} \cdot \mathrm{m}^{-2}\right)$ & 355.65 & 223.26 & 294.00 \\
$H\left(\mathrm{~W} \cdot \mathrm{m}^{-2}\right)$ & 180 & 62.16 & 73.48 \\
$L E\left(\mathrm{~W} \cdot \mathrm{m}^{-2}\right)$ & 103 & 136 & 180.88 \\
$G\left(\mathrm{~W} \cdot \mathrm{m}^{-2}\right)$ & -7.00 & -1.59 & -1.61 \\
$H / R n$ & 0.51 & 0.26 & 0.24 \\
$L E / R n$ & 0.28 & 0.60 & 0.58 \\
$G / R n$ & -0.03 & -0.01 & -0.01 \\
$\mathrm{ET}(\mathrm{mm})$ & 5.53 & 7.35 & 7.16 \\
\hline
\end{tabular}

To quantify the partitioning of $H, L E$, and $G$ over $R n$, we only used the data from 0600 to 1800 Thailand Standard Time (THA) during each period (Table 1). This period was chosen because the atmospheric surface layer is in the unstable phase with positive average net radiation $(R n)$, providing more robust data. Figure 3 shows the diurnal variation in the ensemble half-hourly means of $R n, L E, H$, and $G$ during each period at the study site. The daily maximum of $R n$ during each period was 620.35 and $537.44 \mathrm{~W} \cdot \mathrm{m}^{-2}$ for the leaf senescence period and leaf expansion and foliage stages, respectively. $L E$ showed variations at each period with values ranging from 0.05 to $240.87 \mathrm{~W} \cdot \mathrm{m}^{-2}$, and 8.04 to 335.93 $\mathrm{W} \cdot \mathrm{m}^{-2}$ in the leaf senescence period, and foliage periods, respectively. The magnitude and scope of variation of $L E$ were distinct in each period. In the foliage periods, $L E$ was the main form of energy exchange and accounted for about $60 \%$ of total energy exchange via heat fluxes (Table 1). In addition, the magnitude and range of $H$ were the largest in the leaf senescence period $(H, 51 \%)$, and the value of $H$ ranged from 0.37 to $341.52 \mathrm{~W} \cdot \mathrm{m}^{-2}$. While, the value of $H$ ranged from 8.86 to $104.46 \mathrm{~W} \cdot \mathrm{m}^{-2}$ during the leaf expansion and foliage period. 


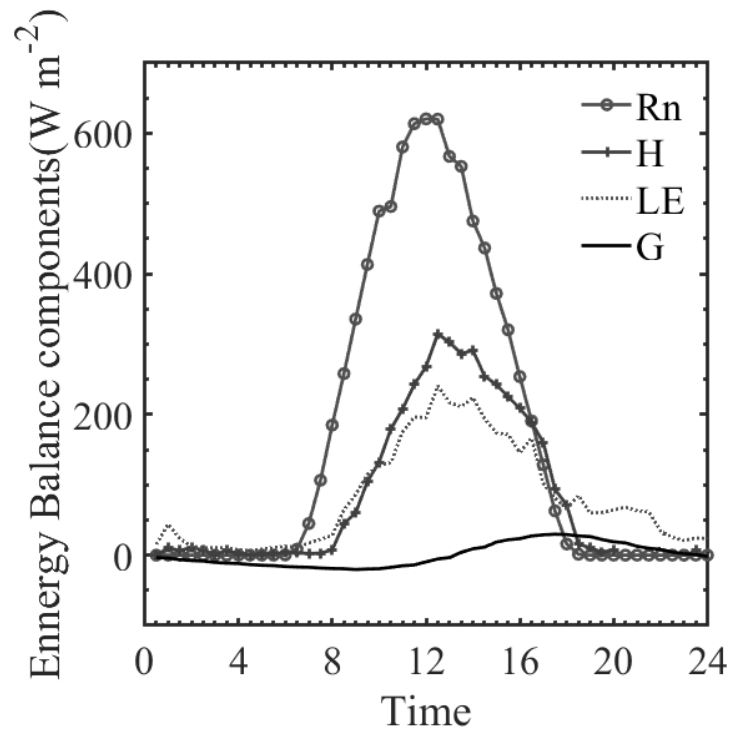

(a) leaf senescence period including coloration and defoliation stages

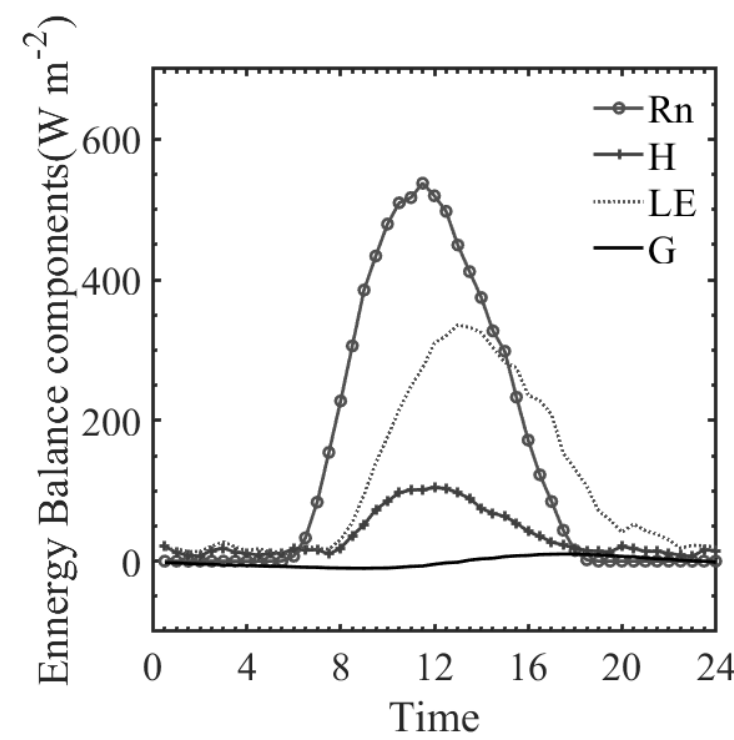

(b) the leaf expansion and foliage stage

Figure 3. Averaged diurnal variations of net radiation flux $(R n)$, latent heat flux $(L E)$, sensible heat flux $(H)$ evaluated from sonic anemometer data, and soil heat flux $(G)$ in the following periods: (a) the leaf senescence period including coloration and defoliation stages (DOY 30 - 58); and (b) the leaf expansion and foliage stage (DOY 90 - 270).

\section{Energy balance and evapotranspiration}

The result of energy balance closure was determined by a linear regression method using $30 \mathrm{~min}$ averaged fluxes. The energy closure of the ecosystem was approximately $78 \%(H+L E=0.78 *(R n-G)$ $+101, \mathrm{R}^{2}=0.62$, and $\left.n=12,912\right)$ over the entire study period. The energy balance closure in this study (78\%) which agrees well within the range of values achieved at 22 FLUXNET sites: Slope: 0.55 - 0.99 ; $r^{2}: 0.64-0.96$ [13], riparian forest in the western US (75\%) [14] and Northwest China (72\%) [15]. The value of energy balance closure in the present study also showed reasonable agreement with the results found by Stoy et al.[16] in short canopy ecosystem such as crops, deciduous broadleaf forests, mixed forests, and wetlands $(70-78 \%)$. On the other hand, the obtained value was lower than similar observations in rubber forest in northeast Thailand and Central Cambodia, which were $83 \%$ and $84 \%$, respectively [4]. This value is relatively low when compared to that reported in young secondary dry dipterocarp forest in western Thailand (83 - $87 \%$ ) [20], boreal forests (94\%) [21], evergreen broadleaf forests and savannas (91 - $94 \%$ ) [19], and high latitude agroecosystem (95\%) [22,23]. The issue on the general lack of energy balance closure has been the topic of much discussion during the past few decades $[16,19,24-26]$. The larger closure found in these studies can be explained due to the incorporation of the energy storage terms, which we neglected in the present study. Some studies have shown that incorporating the canopy, photosynthesis energy, and respiration among other energy balance components led to an increase in closure values [27-29]. Change in the heat storage in tree trunks can be estimated at the peaked of $\sim 60 \mathrm{Wm}^{-2}$ in a $40 \mathrm{~m}$ tall evergreen forest at Tumbarumba [30]. The subtraction of this term from the net radiation improved the hourly energy balance closure from $90 \%$ to larger $100 \%$ [31]. In addition, including the change in biomass in the heat storage component was shown to significantly improve half-hour energy balance closure for a Scandinavian forest [32]. On the other hand, we assumed that the effect of surface heterogeneity during the leaf senescence and expansion period may partly affect 
http://wjst.wu.ac.th

the energy balance closure. Hence, further investigations and comparisons among differences on leaf stages are needed in order to further assess the extent of this variability.

The daily ET over the rubber forest exhibited distinct variation at different stages of growth as indicated in Figure 2c. There was no ET data in January because of the system failure. The mean daily ET was $7.35 \mathrm{~mm} \cdot \mathrm{d}^{-1}$ over rubber forest during the foliage period and a lower rate of ET was found during the leaf senescence period $\left(5.53 \mathrm{~mm} \cdot \mathrm{d}^{-1}\right)$. The rate of ET in this study was higher compared to results in the northeast Thailand and central Cambodia, with mean value of 4.1 and $4.8 \mathrm{~mm} \cdot \mathrm{d}^{-1}$ [5]. Sangwangsri et al. [20] indicated a positive correlation of ET with precipitation, soil water content, and vapor pressure deficit in the dry dipterocarp forest, Western Thailand. Much higher rate of ET in this study is related to the high amount of precipitation that have been collected in 2017. This increases water storage in the soil profile and canopy intercept driving a higher than normal rate of ET during both periods in the rubber forest under study.

\section{Conclusions}

Energy balance partitioning and evapotranspiration of rubber forest in southern region were analyzed using EC method. Energy exchanges between this forest and the atmosphere were dominated by sensible heat fluxes during the leaf senescence period and latent heat fluxes during the leaf expansion and foliage period. The energy balance closure was approximately $78 \%$ over entire period. The ratio of the latent heat $(L E)$, sensible heat $(H)$, and soil $(G)$ heat fluxes to net radiation were $0.58,0.24$, and -0.01 , respectively. In terms of global energy exchanges, results showed that $R n$ was mostly converted into $H$ in the leaf senescence period. The energy balance closure of rubber forest was in the lower range compared to the reported other forest types. On the other hand, the evapotranspiration in rubber forest was high throughout the entire period. A significant increase in ET of roughly $50 \%$ was found when comparing the leaf expansion period to the defoliation period in the rubber forest. Therefore, achieving a better understanding on the fluxes and energy ratios through forest vegetative pattern helps in tracking the amount of water released through ET, which is needed by the forest to sustain an acceptable rubber quality.

\section{Acknowledgements}

This work was financially supported by Thailand Research Fund (Grand No MRG5980199). The authors also acknowledge Surat Thani Rajabhat University, and DORAS Centre, Kasetsart University for providing sharing instrument and data collection. Special thanks to the Rubber State Organization, Nabon district, Nakhon Si Thammarat province for the support and for the facilities used in conducting research.

\section{References}

[1] D Workman. Natural Rubber Exports by Country. World's top export, Available at: http://www.worldstopexports.com/natural-rubber-exports-country/3354, accessed January 2019.

[2] Thailand Foreign Agricultural Trade Statistics 2017. Office of Agriculture Economics, Available at: http://www.oae.go.th/assets/portals/1/files/jounal/2561/thailandtradestat2560.pdf, accessed February 2019.

[3] ZL Wu, HM Liu and LY Liu. Rubber cultivation and sustainable development in Xishuangbanna, China. Int. J. Sustain. Dev. World Ecol. 2011; 8, 337-45.

[4] ZH Tan, YP Zhang, QH Song, WJ Liu, XB Deng, JW Tang, Y Den, WJ Zhou, LY Yang, GR Yu, $\mathrm{XM}$ Sun and NS Liang. Rubber plantations act as water pumps in tropical China. Geophys. Res. Lett. 2011, 38, L24406.

[5] TW Giambelluca, RG Mudd, W Liu, AD Ziegler, N Kobayashi, T Kumagai, Y Miyazawa, TK Lim, M Huang, J Fox, S Yin, SV Mak and P Kasemsap. Evapotranspiration of rubber (Hevea brasiliensis) cultivated at two plantation sites in Southeast Asia. Water Resour. Res. 2016; 52, 66079. 
http://wjst.wu.ac.th

[6] AD Ziegler, J Phelps, JQ Yean, EL Webb, D Lawrence, JM Fox, TB Bruun, SJ Leisz, CM Ryan, W Dressler, O Mertz, U Pascual, C Padoch and LP Koh. Carbon outcomes of major land-cover transitions in SE Asia: Great uncertainties and REDD+ policy implications. Global Change Biol. 2012; 18, 3087-99.

[7] J Fox. Through the technology lens: The expansion of rubber and its implications in montane mainland Southeast Asia. Conservat. Soc. 2014; 12, 418-24.

[8] SO Chung and R Horton. Soil heat and water flow with a partial surface mulch. Water Resour. Res. 1987; 23, 2175-86.

[9] HJH Franssen, R Stöckli, I Lehner, E Rotenberg and SI Seneviratne. Energy balance closure of eddy-covariance data: A multisite analysis for European FLUXNET stations. Agr. Forest Meteorol. 2010; 150, 1553-67.

[10] R McGloin, L Šigut, K Havránková, J Dušek, M Pavelka and P Sedlák. Energy balance closure at a variety of ecosystems in Central Europe with contrasting topographies. Agr. Forest Meteorol. 2018; 248, 418-31.

[11] D Starkenburg, S Metzger, GJ Fochesatto, JG Alfieri, R Gens, A Prakash and J Cristobal. Assessment of de-spiking methods for turbulent flux computations in high latitude forest canopies using sonic anemometers. J. Atmos. Ocean. Tech. 2016; 33, 2001-13.

[12] CJ Moore. Frequency response corrections for eddy correlation systems. Boundary-Layer Meteorol. $1986 ; 37,17-35$.

[13] G Burba, A Schmidt, RL Scott, T Nakai, J Kathilankal, G Fratini, C Hanson, B Law, DK McDermitt, R Eckles, M Furtaw and $M$ Velgersdyk. Calculating $\mathrm{CO}_{2}$ and $\mathrm{H}_{2} \mathrm{O}$ eddy covariance fluxes from an enclosed gas analyzer using an instantaneous mixing ratio. Global Change Biol. 2012; 18, 385-99.

[14] D Starkenburg, GJ Fochesatto, A Prakash, J Cristóbal, R Gens and DL Kane. The role of coherent flow structures in the sensible heat fluxes of an Alaskan boreal forest. J. Geophys. Res. Atmos. 2013; 118, 8140-55.

[15] D Starkenburg, GJ Fochesatto, J Cristóbal, A Prakash, R Gens, JG Alfieri, H Nagano, Y Harazono, $\mathrm{H}$ Iwata and DL Kane. Temperature regimes and turbulent heat fluxes across a heterogeneous canopy in an Alaskan boreal forest. J. Geophys. Res. Atmos. 2015; 120, 1348-60.

[16] K Wilson, A Goldstein, E Falge, M Aubinet, D Baldocchi, P Berbigier, C Bernhofer, R Ceulemans, H Dolman, C Field, A Grelle, A Ibrom, BE Law, A Kowalski, T Meyers, J Moncrieff, R Monson, W Oechel, J Tenhunen, R Valentini and S Verma. Energy balance closure at FLUXNET sites. Agr. Forest Meteorol. 2002; 113, 223-43.

[17] J Kochendorfer, EG Castillo, E Haas, WC Oechel and PUK Tha. Net ecosystem exchange, evapotranspiration and canopy conductance in a riparian forest. Agr. Forest Meteorol. 2011; 151, 544-53.

[18] X Ma, Q Feng, Y Su, T Yu and H Jin. Forest evapotranspiration and energy flux partitioning based on eddy covariance methods in an arid desert region of Northwest China. Adv. Meteorol. 2017, 2017, 1619047.

[19] PC Stoy, M Mauder, T Foken, B Marcolla, E Boegh, A Ibrom, MA Arain, A Arneth, M Aurela, C Bernhofer, A Cescatti, E Dellwik, P Duce, D Gianelle, EV Gorsel, G Kiely, A Knohl, H Margolis and A Varlagin. A data-driven analysis of energy balance closure across FLUXNET research site: The role of landscape scale heterogeneity. Agr. Forest Meteorol. 2013; 152, 137-52.

[20] M Sanwangsri, P Hanpattanakit and A Chidthaisong. Variations of energy fluxes and ecosystem evapotranspiration in a young secondary dry dipterocarp forest in Western Thailand. Atmosphere $2017,8,152$.

[21] JM Sánchez, V Caselles and EM Rubio. Analysis of the energy balance closure over a FLUXNET boreal forest in Finland. Hydrol. Earth Syst. Sci. 2010; 14, 1487-97.

[22] W Ruairuen, GJ Fochesatto, EB Sparrow, W Schnable, M Zhang and Y Kim. Evapotranspiration cycles in a high latitude agroecosystem: Potential warming role. PloS One 2015; 10, e0137209. 
[23] W Ruairuen, GJ Fochesatto, M Bitelli, EB Sparrow, W Schnable and M Zhang. Evapotranspiration in Northern agro-ecosystems: Numerical simulation and experimental comparison. In: D Bucur (Ed.). Current Perspective to Predict Actual Evapotranspiration, IntechOpen, 2017, p. 65-84.

[24] D Charuchittipan, W Babel, M Mauder, JP Leps and T Foken. Extension of the averaging time in eddy-covariance measurements and its effect on the energy balance closure. Boundary-Layer Meteorol. 2014; 152, 303-27.

[25] F Eder, FD Roo, K Kohnert, RL Desjardins, HP Schimid and M Mauder. Evaluation of two energy balance closure parametrizations. Boundary-Layer Meteorol. 2014; 151, 195-219.

[26] Z Gao, H Liu, GG Katul and T Foken. Non-closure of the surface energy balance explained by phase difference between vertical velocity and scalars of large atmospheric eddies. Environ. Res. Lett. 2017; 12, 034025.

[27] M Zeri, LDA Sá, AO Manzi, AC Araujo, RG Aguiar, CV Randow, G Sampaio, FL Cardoso and CA Nobre. Variability of carbon and water fluxes following climate extremes over a tropical forest in Southwestern Amazonia. PloS One 2014; 9, e88130.

[28] R Eshonkulov, A Poyda, J Ingwersen, A Pulatov and T Streck. Improving the energy balance closure over a winter wheat field by account for minor storage terms. Agr. Forest Meteorol. 2019; 264, 283-96.

[29] S Kutikoff, X Lin, S Evett, P Gowda, J Moorhead, G Marek, P Colaizzi, R Aiken and D Brauer. Heat storage and its effect on the surface energy balance closure under advective conditions. Agr. Forest Meteorol. 2019; 265, 56-69.

[30] R Leuning, HA Cleugh, SJ Zegelin and D Hughes. Carbon and water fluxes over a temperate Eucalyptus forest and a tropical wet/dry savanna in Australia: Measurements and comparison with MODIS remote sensing estimates. Agr. Forest Meteorol. 2005; 129, 151-73.

[31] V Haverd, M Cuntz, R Leuning and H Keith. Air and biomass heat storage fluxes in a forest canopy: Calculation within a soil vegetation atmosphere transfer model. Agr. Forest Meteorol. 2007; 147, 125-39.

[32] A Lindroth, M Molder and F Lagergren. Heat storage in forest biomass improves energy balance closure. Biogeosciences 2010; 7, 301-13. 